\title{
FACTORS AFFECTING COMPULSORY PURCHASE OF LAND FOR PUBLIC NEEDS IN UKRAINE
}

\author{
Alina Lizunova \\ Kyiv National University of Construction and Architecture
}

\begin{abstract}
At the current stage of adapting the goals of the Sustainable Development Concept, compulsory purchase of land to meet public needs may be an effective tool. Public needs may require privately owned land, but it is sometimes only possible to negotiate with the owners through the land compulsory purchase mechanism.

When implementing such projects it is necessary to take into account certain factors that have an impact on this process at each stage of the execution of works. To determine these factors is necessary to make some analysis that will identify primary and secondary factors determine their importance and divide them into certain groups.

To determine the main groups of factors should be used PEST analysis technique that is often used to assess key market trends. The results of PEST analysis can be used to determine the list of threats and opportunities for the implementation of projects for the construction of linear objects of transport infrastructure, it is advisable to supplement the basic elements of PEST analysis, such as Politic (P), Economic (E), Social (S) and Technical (T), with the following indicators: P (Planning) E (Environmental), L (Legal).

Through PEST analysis is necessary to determine each factor and not just describe the current status, and predict its change over the next 3-5 years. The most important and the most difficult are to determine the balance between the factors and to account for their interaction.
\end{abstract}

Key words: sustainable development, compulsory purchase, public needs, transport infrastructure, PEST.

\section{Introduction}

Sustainable development requires the Governments of the countries to establish and maintain in a functional conditions social and engineering infrastructure facilities that provide security, healthy living conditions, well-being, socio-economic development, protection and restoration of the natural environment. One of the first steps in the realization of these tasks is the acquisition of the relevant land. In some cases, there may be several options, for example, the construction of a new pre-school educational establishments, and the Government may purchase a land in a free land market. In other cases, the objects should be located in a certain place - it is about building new infrastructure.

The necessary land plot may not be available for sale at a time when the Government needs it. In order to get the land at the right place and at the right time the Government uses the right to compulsory purchase the land, this right involves forcing the owners to sell their land in order to meet certain public needs.

Compulsory purchase of land for the purpose of their development certainly brings benefits to society. When the government conducts the alienation process in a satisfactory manner, citizens and communities are left in a situation similar to that in which they were before the land alienation and society receives the benefits provided.

The purpose of the article is to analyze the legislation of Ukraine regarding compulsory purchase of land plots to meet the public needs and formulate a list of these needs. Identify groups of factors that may have an impact on the location of infrastructure based on an analysis of the list of public needs and sustainable development trends.

\section{Methodology of research and materials}

Ukraine, like other UN member states, has joined the global process of sustainable development. To achieve the Sustainable Development Goals (The Global Goals, 2015), the Ukraine 2020 Sustainable Development Strategy has been developed (Sustainable Development Strategy "Ukraine 2020", 2015). The aim of the Strategy is to introduce European standards of living in Ukraine and Ukraine's leading position in the world.

Compulsory purchase is the transfer of ownership of land and other immovable property located thereon, which are owned by individuals or legal entities for payment, in state or municipal property by means of redemption for the needs of state, local community or society. This procedure is often necessary for the purposes of socio-economic development and environmental protection. 


\section{Discussions and results}

Compulsory purchase is the transfer of ownership of land and other immovable property located thereon, which are owned by individuals or legal entities for payment, in state or municipal property by means of redemption for the needs of state, local community or society. This procedure is often necessary for the purposes of socio-economic development and environmental protection.

Compulsory purchase of land plots to meet public needs in Ukraine is regulated by the Constitution of Ukraine (Constitution, 1996), the Civil Code of Ukraine (Code, 2003), the Land Code of Ukraine (Code, 2001), and other legal acts.

The realization and effective provision of public land needs are impossible without the existence of a proper legal mechanism for the purchase of land from private owners and the protection of their rights and interests, the use of which enables the state to forcibly alienate private land for use in the public interest.

The rules of the Land Code of Ukraine enshrine the legal foundations of land redemption and their compulsory purchase to meet public needs, but they are of a general nature and do not regulate the grounds and procedure for compulsory purchase.

In this regard, the Law of Ukraine " On compulsory purchase of land plots, other objects of real estate that are located on them, which are in private ownership, for public needs or from the motives of social necessity" (Law of Ukraine, 2009)was adopted by the Verkhovna Rada of Ukraine on November 17, 2009, which clearly defines the concept of compulsory purchase of land and its variety, as well as the grounds, principles and procedure for compulsory purchase. This law defines the legal, organizational and financial principles of regulation of public relations arising in the course of compulsory purchase of land plots, other real estate objects placed on them, owned by natural or legal persons, for public needs, if the needs cannot be secured by use of state or communal property.

Compulsory expropriation of private property shall be applied only as an exception for the common good on the basis of and according to the rules and procedure established by the law, and on condition of prior and full compensation of its value (Kalbro, 2007). The compensation can take form of monetary value or substituting land plot or the combination of these forms. The compensation should cover not only the value of the land, but also damages, including lost profits. The compensation is based on voluntary agreement or, if not agreed, through the court procedure. In the latter case the «expert monetary evaluation standards» are applied. Legislation conserning compensation are The Law of Ukraine «On the evaluation of lands» (Law of Ukraine, 2003) and The Law of Ukraine «On the evaluation of property, property rights and professional valuation activity in Ukraine» (Law of Ukraine, 2001).

Legal aspects of dispossession described in terms of legal capacity of owners of land at the disposal of land for public needs:

- if the owner of land (part), which is dispossessed, is also the owner of the house, other buildings, structures, perennial crops, the requirement on dispossession of land treated with request to terminate the ownership of these objects;

- if the plot of land leased and / or collateral to participate in negotiations involving the owners of these facilities, tenants and / or the mortgagee, but the question of compensation open to them;

- payment of compensation for rights that are not defined legally can be a difficult political task, this issue is very acute now in Ukraine.

Ukrainian legislation tends to exclude the payment of compensation for the value of land to persons who are legally vague right to a house. However, if residents are deemed to deserve special assistance, the government must provide the displacement of other land.

Space-technical aspects of dispossession described in terms of planning capabilities at dispossession of land for public purposes:

- if dispossessed the entire plot of land then the owner refunded the entire cost of land;

- in cases where part of the land and part of the house is dispossessed, and another part may be used inappropriately - these issues are not clear in Ukrainian legislation;

- in the case of part land dispossession, and the rest of the area cannot reasonably be used, at the request of the owner of land dispossession is subject to the entire plot.

Infrastructure is a set of operating structures, buildings, networks, and systems that are not directly related to the production of material goods, but which are necessary for the functioning of the branches of material production and to ensure the conditions of life of society. 
The infrastructure of territories, according to its relation to material production, is classified into the following main types:

- a production infrastructure that provides the necessary logistical facilities for the location and operation of public production within a specific territory (roads, ports, bridges, communication systems, etc.);

- social infrastructure that provides the necessary housing, living and socio-cultural conditions for the population of the area, city, region, agglomeration (educational institutions, culture, health care, public services).

In the production infrastructure class, there are separate subclasses:

- transport infrastructure - a system of transport communications, vehicles and equipment providing freight and passenger transportation in a certain territory,

- engineering infrastructure - a system of engineering networks and structures providing water, sewerage, energy supply, communications, lighting, etc. in a specific area.

The social infrastructure of the population includes housing and communal services, retail, household and catering establishments, educational, scientific and cultural institutions, health and sports institutions and more.

The Law of Ukraine " On compulsory purchase of land plots, other objects of real estate that are located on them, which are in private ownership, for public needs or from the motives of social necessity" stipulates that executive bodies and local self-government bodies have the right to buy out land plots owned by natural or legal persons for the following public purposes (Law of Ukraine, 2009):

- ensuring national security and defense;

- construction, repair, reconstruction and maintenance of linear objects and objects of transport and energy infrastructure and facilities necessary for their operation;

- placement of foreign diplomatic missions and consular posts, representations of international organizations in Ukraine in accordance with international treaties of Ukraine;

- placing and maintenance of facilities related to mining;

- construction of protective hydraulic structures;

- creation of city parks, construction of pre-school educational establishments, recreation grounds, stadiums and cemeteries;

- construction and maintenance of oil and gas wells and production facilities required for their operation, facilities for underground storage of oil, gas and other substances and materials;

- location of nature reserve fund objects.

As can be seen from the list of public needs, construction, overhaul, reconstruction and maintenance of linear objects of transport infrastructure and objects necessary for their operation, occupies a separate place and is relevant in the Concept of Sustainable Development of Ukraine (Law of Ukraine, 2009).

When implementing projects for the placement of linear objects of transport infrastructure, it is necessary to take into account certain factors that have an impact on this process at each stage of the work. In order to identify these factors, some analysis is needed to identify the major and additional factors, determine their importance, and divide them into specific groups.

To identify groups of factors when designing any transport infrastructure project, it is advisable to use the PEST analysis technique, which is often used to evaluate key market trends. The results of PEST analysis can be used to determine the list of threats and opportunities for the implementation of these investment projects. In terms of designing transport infrastructure objects, PEST may be an abbreviation of the following indicators: Politic (P), Economic (E), Social (S) and Technical (T). (Fig.1).

$\mathrm{P}$ (Politic) - factors of the political and legal environment. In analyzing this indicator, it is recommended to answer questions about key changes in political stability and regulation. 


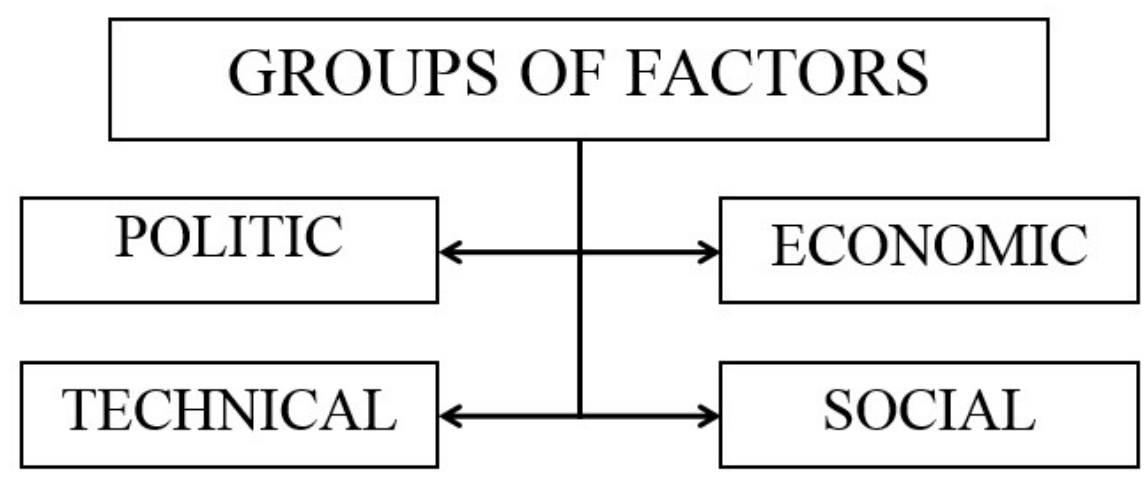

Fig. 1. Groups of factors of PEST analysis

$\mathrm{E}$ (Economic) - factors of economic condition. In the analysis of this group of factors, it is necessary to identify not only key parameters characterizing the state of the country's economy, but also the economic indicators of the future project. If we look in more detail form the basis of the principles of sustainable development, we can state that the basic elements of the group of Economic factors are: costs of pre-project research, project development costs, cost of funds involved, the total cost of buying out land plots, compensation costs, the expected net profit from the project implementation, cost-to-earnings ratio of the project, the impact of the infrastructure on the economic situation in the region.

S (Social) - factors of social impact of the project and social attitude towards the project. The main factors in the group of Social factors are: the relevance of the project to the public need and its importance for the development of society and the region, preservation of historical and cultural monuments, public interest in project results and public opinion, population attitudes to the project, employment of the population during the project implementation.

$\mathrm{T}$ (Technical) are the factors that characterize the technical process of project development and execution. This group of factors requires detailed analysis, because in the era of technological progress, it is the change in technology that can dramatically change approaches to project implementation. Regarding transport infrastructure projects it is important to consider the need for additional works on strengthening the soil cover and increasing its carrying capacity

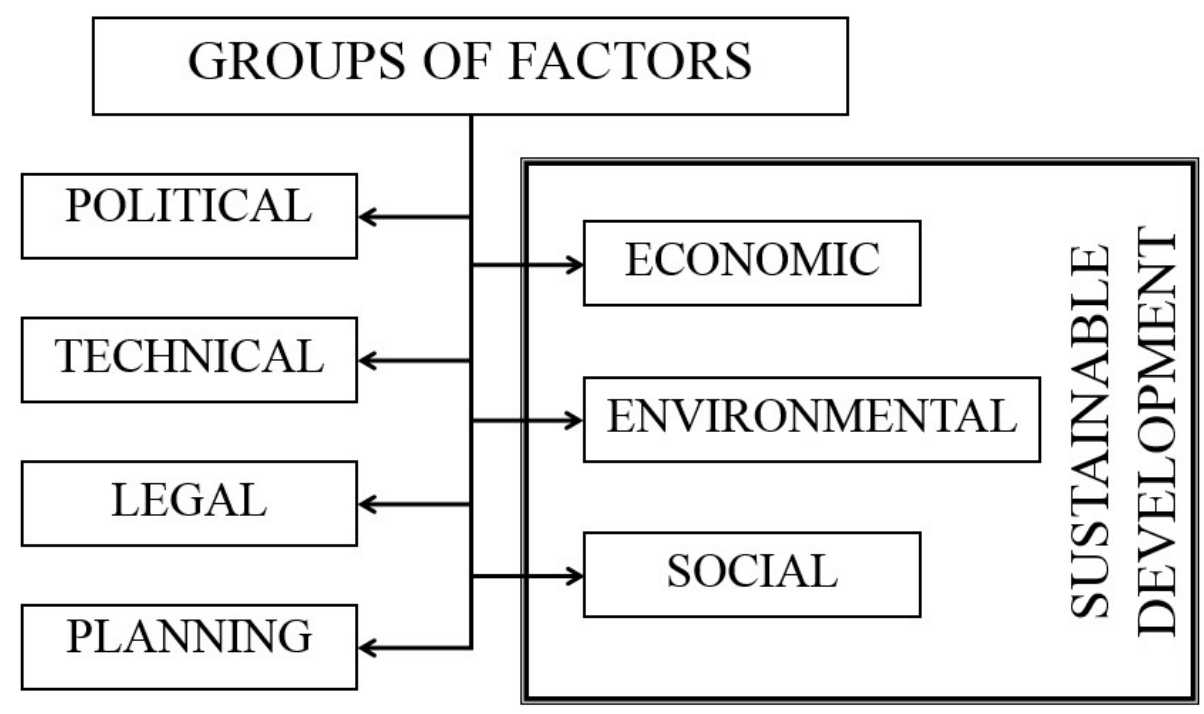

Fig. 2. Groups of factors that affect the placement of transport infrastructure.

PEST analysis is a tool that allows you to assess the impact of external factors and risks in the implementation of transport infrastructure projects. Like any tool, it can change and acquire new variations. In the situation of development of projects of construction, overhaul and reconstruction of objects of transport infrastructure, in the context of ensuring sustainable development (Sustainable Development Strategy "Ukraine 2020", 2015), it is advisable to supplement the basic elements of PEST analysis by Environmental (E), Legal (L) and Planning (P) factors (Fig. 2). 
E (Environmental) - environmental factors determine the degree of project impact on the environmental situation in the region, as well as environmental factors that may affect the effectiveness of the project. The main factors in the group of Environmental factors are those that affect (Lizunova, 2019): pollution of land resources, water pollution, air pollution, impact on living organisms and humans.

L (Legal) are the factors that characterize compliance of the project with the norms and rules of the current Ukrainian legislation.

P (Planning) are the factors that characterize compliance of the project: with the approved urban planning documentation, with the economic planning and functional zoning of the territory

The most important and difficult is to determine the balance not only between all groups of factors but also to take into account their interaction

\section{Conclusions and proposals}

PEST analysis is a tool that allows you to evaluate the impact of external factors and risks in the process of project implementation, and like any tool, it is easy to change and acquire new variations. In developing projects for the construction of linear transport infrastructure objects and in the context of sustainable development, it is advisable to supplement the groups of political, economic, socioal and technical factors with legal factors, which will determine the compliance of the project with current legislative and regulatory requirements, environmental factors, that determine the degree of impact of the project on the environmental situation in the region, as well as planning factors that can affect the effectiveness of the project.

When implementing investment projects for construction, overhaul and reconstruction of linear objects of transport infrastructure within the framework of the Transport Strategy of Ukraine, it is advisable to use multicriteria optimization methods. However, the effectiveness of the decision-making process depends on the structuring of the factors that serve as the criteria for decision selection.

\section{References}

1. Constitution of Ukraine N 30 dated 22.06 .1996 https://zakon.rada.gov.ua/laws/show/254\%D0\%BA/96$\% \mathrm{D} 0 \% \mathrm{~B} 2 \% \mathrm{D} 1 \% 80 \# \mathrm{n} 4976$

2. Civil Code of Ukraine N 435-IV dated 16.01.2003 https://zakon.rada.gov.ua/laws/main/435-15

3. Kalbro, T. 2007. Private Compulsory Acquisition and the Public Interest Requirement. Paper to the FIG (International Federation of Surveyors) Helsinki Semi-nar on Compulsory Purchase, 6-8 September.

4. Land Code of Ukraine N 2768-III dated 25.10.2001 https://zakon.rada.gov.ua/laws/show/2768-14

5. Law of Ukraine "On compulsory purchase of land plots, other objects of real estate that are located on them, which are in private ownership, for public needs or from the motives of social necessity" N 1559-VI dated 17.11.2009 https://zakon.rada.gov.ua/laws/show/1559-17

6. Law of Ukraine «On the evaluation of lands» N 1378-IV dated 11.12.2003 https://zakon.rada.gov.ua/laws/show/1378-15\#n205

7. Law of Ukraine «On the evaluation of property, property rights and professional valuation activity in Ukraine» N 2658-III dated 12.07.2001 https://zakon.rada.gov.ua/laws/show/2658-14

8. Lizunova, A. 2019. Consideration of Ecological Factors in Compulsory Purchase of Land when Placing Objects of Transport Infrastructure, Journal of Ecological Engineering Vol 20(1), pp. 220-227

9. Lizunova, A., 2019 Decision-making in the implementation of investment projects in the transport industry. Management of the development of complex systems. 38, 186- 192

10. The Global Goals Sustainable Development 2030 https://www.globalgoals.org/

11. Sustainable Development Strategy "Ukraine 2020". Presidential Decree No. 5/2015 of 12.01.2015 http://zakon.rada.gov.ua/laws/show/5/2015

Alina Lizunova, $\mathrm{PhD}$, Associate Professor, Docent, Land Management and Cadastre Department Kyiv National University of Construction and Architecture, Kyiv, Ukraine, ORCID 0000-0003-1571-4463 Address, phone, email lizunova.ap@knuba.edu.ua. Fields of interest. 